\title{
Heat stress and workload associated with sugarcane cutting - an excessively strenuous occupation!
}

\author{
Rebekah Al Lucas ${ }^{1 *}$, Theo Bodin², Ramon García-Trabanino ${ }^{3}$, Catharina Wesseling ${ }^{2}$, Jason Glaser ${ }^{4}$, Ilana Weiss ${ }^{4}$, \\ Emmanuel Jarquin ${ }^{5}$, Kristina Jakobsson ${ }^{6}$, David H Wegman ${ }^{7}$
}

From 15th International Conference on Environmental Ergonomics (ICEE XV)

Portsmouth, UK. 28 June - 3 July 2015

\section{Introduction}

Chronic kidney disease not associated with traditional risk factors (sometimes called Mesoamerican nephropathy) is prevalent in male agricultural labourers, particularly sugarcane cutters, in Central America and Mexico regions [1]. Strenuous work in a hot environment with dehydration is believed to be a key causal factor [1]. The aim of this study was to assess the level of heat stress and workload in sugarcane cutters.

\section{Methods}

45 sugarcane cutters (34(12) y; range $18-57$ y) from El Salvador were studied during the 2015 harvest (FebApril). Heart rate (HR, Polar) was recorded in 10-11 workers per day, during 7 workdays. Weather data was collected using two weather stations (Weatherhawk, QuesTemp $\left.{ }^{\circ} 34\right)$. Outdoor Wet Bulb Globe Temperatures (WBGT) was calculated (WBGT (outdoor) = $0.7 \mathrm{WB}+0.2 \mathrm{G}+0.1 \mathrm{DB})$ via the QuesTemp ${ }^{\circ} 34$. HR data were expressed a percentage of maximal $\mathrm{HR}\left(\% \mathrm{HR}_{\max }\right)$. A regression equation was used to predict $\mathrm{HR}_{\max }(208$ $0.7 \times$ age) $[2]$.

\section{Results}

Sugarcane cutters worked on average for 7:30 hours (range 3:20 - 9:36 hours). In the field, WBGT reached $32.1^{\circ} \mathrm{C}$ (95\% confidence interval $[\mathrm{CI}]: 33.0^{\circ} \mathrm{C}$ to $31.1^{\circ} \mathrm{C}$ ), with $79 \%$ (95\% CI: 87 to $71 \%$ ) of the day spent working at a WBGT above $26^{\circ} \mathrm{C}$ (threshold limit for continuous harvesting at $100 \%$ [3]). Heart rates averaged $54 \%$

\footnotetext{
* Correspondence: r.a.i.lucas@bham.ac.uk

${ }^{1}$ School of Sport, Exercise and Rehabilitation Sciences, University of Birmingham, UK

Full list of author information is available at the end of the article
}

$\mathrm{HR}_{\max }$ (95\% CI: 57 to $52 \% \mathrm{HR}_{\max }$ ) across all workdays. Workers spent 4:44 hours (95\% CI: 5:19 to 4:09 hours) working at $\geq 50 \% \mathrm{HR}_{\max }$ and 2:48 hours (95\% CI: 3:21 to 2:15 hours) working $<50 \% \mathrm{HR}_{\max }$.

\section{Discussion}

Sugarcane cutting is repetitive high-intensity work carried out in high heat stress conditions. Workers spent over half the workday (including rest breaks) working at and above $50 \%$ of their $\mathrm{HR}_{\max }$. This HR intensity is similar to that exhibited in the first 12 hours of adventure racing $\left(64 \% \mathrm{HR}_{\max }[4]\right)$ and higher than that maintained by soldiers during multi-day operations $(30-40 \%$ of aerobic power [5]).

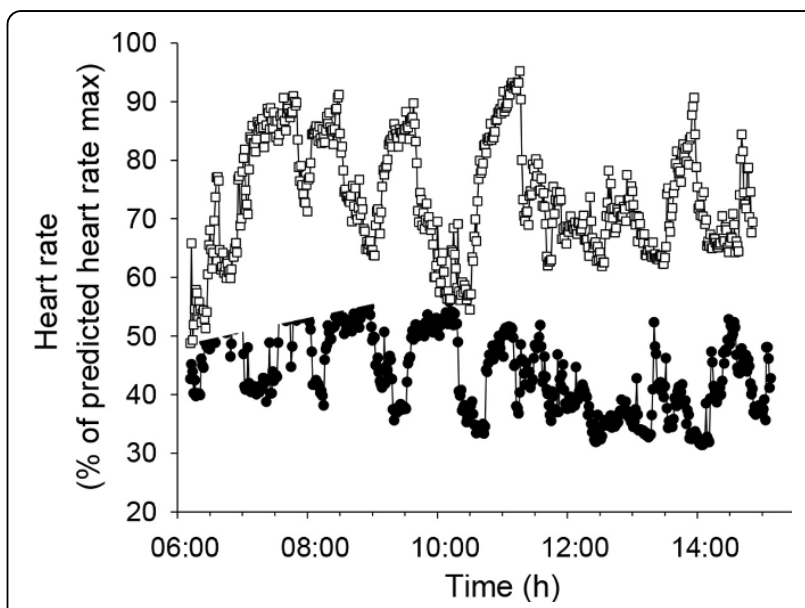

Figure 1 Heart rate (1 min intervals) during one workday for two sugarcane workers. 


\section{Conclusion}

The cardiac strain of sugarcane cutting is similar to that associated with very prolonged, competitive exercise and higher than that typically associated with self-paced hard work. Yet, sugarcane cutters maintain this work intensity daily throughout the harvest ( $\sim 6$ months).

\section{Authors' details}

'School of Sport, Exercise and Rehabilitation Sciences, University of Birmingham, UK. ${ }^{2}$ Unit of Occupational Medicine, Karolinska Institutet, Sweden. ${ }^{3}$ Scientific Board, Department of Investigation, Hospital Nacional Rosales, El Salvador. ${ }^{4}$ La Isla Foundation, IL, USA/El Salvador. ${ }^{5}$ Agency for Agricultural Health and Development (AGDYSA), El Salvador. ${ }^{6}$ Occupational and Environmental Medicine, University of Gothenburg, Sweden.

${ }^{7}$ Department of Work Environment, University of Massachusetts Lowell, MA, USA.

Published: 14 September 2015

\section{References}

1. Wesseling C, Crowe J, Hogstedt C, Jakobsson K, Lucas R, Wegman DH: Resolving the enigma of the mesoamerican nephropathy: a research workshop summary. American Journal of Kidney Diseases 2014, 63(3):396-404

2. Tanaka, Hirofumi, Monahan, Kevin D, Seals, Douglas R: Age-predicted maximal heart rate revisited. Journal of the American College of Cardiology 2001, 37(1):153-156

3. Crowe, Jennifer, Wesseling, Catharina, Solano, Bryan Román, Umaña, Pinto Manfred, Ramírez, Robles Andrés, Kjellstrom, Tord, Nilsson, Maria: Heat exposure in sugarcane harvesters in Costa Rica. American Journal of Industrial Medicine 2013, 56(10):1157-1164.

4. Lucas SJ, Anglem N, Roberts WS, Anson JG, Palmer CD, Walker RJ, Cotter JD: Intensity and physiological strain of competitive ultraendurance exercise in humans. Journal of sports sciences 2008, 26(5):477-489.

5. Myles WS, Eclache J, Beaury J: Self-pacing during sustained, repetitive exercise. Aviation, space, and environmental medicine 1979, 50(9):921-924.

doi:10.1186/2046-7648-4-S1-A23

Cite this article as: Lucas et al:: Heat stress and workload associated with sugarcane cutting - an excessively strenuous occupation!. Extreme Physiology \& Medicine 2015 4(Suppl 1):A23.

\section{Submit your next manuscript to BioMed Central and take full advantage of:}

- Convenient online submission

- Thorough peer review

- No space constraints or color figure charges

- Immediate publication on acceptance

- Inclusion in PubMed, CAS, Scopus and Google Scholar

- Research which is freely available for redistribution

Submit your manuscript at www.biomedcentral.com/submit
C Biomed Central 